\title{
Supreme Court of Canada Cases Strengthen ARGUMENT FOR MUNiCIPAL OBLIGATION TO DisCHARGE DUTY TO CONSULT: Time to Put Neskonlith to Rest
}

\author{
ANGEla D’Elia DeCEMBRINI ${ }^{*}$ AND SHIN IMAI ${ }^{* *}$
}

Can municipalities infringe Aboriginal or treaty rights without consulting the affected Indigenous group? In Neskonlith Indian Band v. Salmon Arm (City), ${ }^{1}$ the British Columbia Court of Appeal answered this question in the affirmative, finding that the city of Salmon Arm did not need to consult the Neskonlith First Nation about impacts from the construction of a shopping mall. In what was technically obiter dicta, the Court permitted the municipal project to proceed, and told the First Nation that its only recourse was to complain to the provincial government in a separate proceeding.

In 2014, Shin Imai and Ashley Stacey in "Municipalities and the Duty to Consult Aboriginal Peoples: A Case Comment on Neskonlith Indian Band v. Salmon Arm (City)"'2 argued that the case was wrongly decided in law and was unworkable in practice. Seven years after the decision, in 2019 , these predictions seem to have come true. The legal reasoning in Neskonlith has been undermined in two decisions of the Supreme Court of Canada dealing with the role of the National Energy Board (NEB) in discharging the Crown's duty to consult. ${ }^{3}$ These cases have confirmed that any project that may impact Aboriginal or treaty rights cannot go ahead unless there is appropriate consultation and accommodation. If the entity empowered to give the green light to the project cannot satisfy the consultation and accommodation required, then the Crown must step in to ensure that the duty to consult is fulfilled.

As for practice on the ground, Neskonlith seems to have been largely ignored. Rather than using the case as a way to implement projects without consultation, provinces and municipalities are going in the opposite direction. Some provinces have enacted statutory provisions requiring municipalities to consult, and individual municipal initiatives meant to foster collaborative relationships with Indigenous people are taking place across Canada.

\section{Why The NeSKonlith Decision WAS Wrongly DeCIDED}

In Neskonlith, the City of Salmon Arm authorized the construction of a shopping mall on a flood plain. The project was so dangerous that a hazardous development permit was required pursuant to Part 26 of the British Columbia Local Government Act. ${ }^{4}$ The Neskonlith First Nation bordered on the development and sought to quash the permit, as they were

** Associate, First Peoples Law, Vancouver, British Columbia.

Professor Emeritus, Osgoode Hall Law School, Toronto, Ontario. This article is written as an initiative of the Justice and Corporate Accountability Project (justice-project.org). The authors wish to thank Alexandra Flynn, Associate Professor, University of Toronto, for sharing her expertise on municipal consultation in Ontario. 2012 BCCA 379 [Neskonlith]. (2014) 47:1 UBC L Rev 293.

Clyde River (Hamlet) v Petroleum Geo-Services Inc, 2017 SCC 40 [Clyde River]; Chippewas of the Thames First Nation v Enbridge Pipelines Inc, 2017 SCC 41 [Chippewas]. RSBC 1996, c 323, replaced by Municipal Replotting Act, RSBC 2016, c 1. 
concerned with the damage that could result in the event of a flood. The First Nation argued that the municipality had a duty to consult. They argued that the provincial Crown had empowered municipalities to make land use decisions, and this delegation of power must necessarily have been accompanied by the delegation of the Province's consultation obligations.

In 2012, the Court of Appeal (per Justice Newbury, with Justices Hall and Smith concurring) dismissed the Neskonlith First Nation's claims and held that municipalities do not have the authority to consult and accommodate First Nations. While the Crown has a duty to consult, the municipality was not the Crown and did not have such a duty. Further, the provincial Crown had not expressly delegated consultation obligations to the City of Salmon Arm. The municipality could therefore proceed with the project without consultation.

The Court emphasized the limited capacity of municipalities to fulfill the duty to consult and accommodate, noting that municipalities were not granted the remedial powers necessary to consult and accommodate Aboriginal interests. The Court also noted the practical challenges faced by municipalities, whose governments range in size and tax base and are mainly concerned with the regulation of privately-owned land. In the Court's assessment, imposing the Crown's duty to consult on local governments would focus consultation and accommodation efforts on "mundane decisions" regarding licences, permits, zoning restrictions, and the like. ${ }^{5}$ As a result, "[d]aily life would be seriously bogged down if consultation — including the required 'strength of claim' assessment — became necessary whenever a right or interest of a First Nation 'might be' affected."'

In their 2014 case commentary, Imai and Stacey suggested that the Court of Appeal had asked the wrong legal question. ${ }^{7}$ The result of an inquiry into who has the duty to consult does not also answer the question about whether consultation is necessary before a project can proceed. These are two separate questions. Irrespective of who must consult, the duty must be met before a project that actually or potentially infringes Aboriginal rights moves forward. ${ }^{8}$

The Court was also wrong about the capacity of municipalities to carry out consultation. As Imai and Stacey pointed out, all municipalities consult with their citizens on a wide range of issues. ${ }^{9}$ In fact, the Court in Neskonlith found that the City of Salmon Arm had carried out an appropriate level of consultation with the Neskonlith First Nation. ${ }^{10}$ 
In this comment, we argue that both local and provincial governments have important roles to play in the consultation process. Where municipalities lack the capacity to fully consult with Indigenous groups, we suggest ways for provinces to work with and assist municipalities as necessary to fulfill the duty to consult. ${ }^{11}$ However, regardless of whether the project proponent is a municipality, a private company, or the Crown, where there has not been adequate consultation and accommodation, the project cannot proceed.

\section{NESKonlith Would CREATE a Legal VACUUM}

Neskonlith created a legal vacuum regarding fulfillment of the Crown's constitutional obligations when local government decisions affect Aboriginal and treaty rights. In the Court's reasoning, local governments, by virtue of their legislative authority to proceed with a project, could freely infringe existing or potential Aboriginal rights without consulting the affected Indigenous peoples, even when the province had not consulted. This reasoning would effectively render any consultation efforts by the Crown meaningless. Even if the Crown determined that some form of accommodation was required to address the potential infringement of the Aboriginal rights in question before a project proceeded, the project could continue on the basis that the local decision-maker was not required to consult.

Whether a particular entity has the duty to consult should not be determinative of whether a project should move forward. Rather, when a project has the potential to affect Aboriginal rights, meaningful consultation and accommodation is required prior to the project's approval. ${ }^{12}$ If the Crown has failed to adequately discharge its constitutional obligations, then this precondition for taking action that may affect Aboriginal rights will not have been met, and the project may not proceed.

We see an illustration of this principle in the case of Ross River Dena Council v. Government of Yukon. ${ }^{13}$ In this case, the Yukon Court of Appeal considered the obligation of the Crown to consult in the context of the "free entry" mining exploration system provided for in the territorial Quartz Mining Act. ${ }^{14}$ Under this system, anyone could acquire mineral rights simply by staking a claim and having it recorded with the Mining Recorder. The Mining Recorder did not possess the discretion to refuse to record a claim that complied with the statutory requirements. Rather, its role in recording the mining claim was purely administrative. Once the mining claim was recorded, the claimant could begin exploration activities without further authorization or notice to the territorial government. Since a mining company, as a private body, does not have an independent duty to consult affected Indigenous people, in Ross River Dena, the question arose as to whether the Crown had such a duty in these circumstances.

In this comment, we only address consultation and accommodation, not consent, because this case comment is restricted to the duties of municipalities in the context of existing Canadian jurisprudence. For an overview of arguments on why consent should be required in certain circumstances, see Shin Imai, "Consult, Consent, and Veto: International Norms and Canadian Treaties" in John Borrows \& Michael Coyle, eds, The Right Relationship: Reimagining the Implementation of Historical Treaties (Toronto: University of Toronto Press, 2017) 370. See also Imai \& Stacey, supra note 2, for a further discussion on opportunities for the provincial and municipal governments to work together to discharge the duty to consult.

Haida, supra note 8 at para 67.

2012 YKCA 14 [Ross River Dena].

SY 2003, c 14. 
If the Court had followed the reasoning in Neskonlith, it would have asked the wrong question - did the private mining company have a duty to consult? Since the mining company was obviously not the Crown, the Court would have found that the company did not have a duty to consult, and would have permitted the company to go ahead and explore, even though the Ross River Dena had not been consulted. The Court of Appeal (per Justice Groberman, with Justices Tysoe and Hinkson concurring), however, asked the right question - was there a potential impact on Indigenous rights, and if so, had there been appropriate consultation and accommodation? Having found that no consultation had taken place, the Court issued a declaration that the legislation be amended to ensure that exploration did not proceed without appropriate consultation and accommodation. ${ }^{15}$

As Imai and Stacey have noted, "[t]he fact that a municipality or a private business does not have the duty to consult does not put them in a better position than the Crown," in that a project cannot proceed until consultation and accommodation has occurred. ${ }^{16}$ The Supreme Court of Canada's judgments in the companion appeals of Clyde River and Chippewas confirm that the duty to consult must be met before a project that has the potential to infringe Aboriginal and treaty rights may proceed.

In Clyde River and Chippewas, the Supreme Court considered the ability of legislatures to empower regulatory bodies, here the NEB, to play a role in fulfilling the Crown's duty to consult. In Clyde River, the proponents sought and were ultimately granted NEB approval to conduct offshore seismic testing for oil and gas resources. The Inuit of Clyde River objected to the testing on the ground that it would negatively impact their harvesting rights. In Chippewas, the Chippewas of the Thames First Nation challenged the proponent's proposal to reverse the flow of an existing pipeline which traversed the Chippewas' traditional territory. The NEB approved the application, imposing conditions on the project that required the proponent to address concerns raised by the Chippewas. The Inuit of Clyde River and the Chippewas each challenged the respective NEB decisions on the basis that the NEB had no legal authority to approve the projects because the Crown's duty to consult with the impacted Indigenous communities had not been adequately discharged.

In both cases, the Supreme Court of Canada explained that the Crown could rely on steps taken by an administrative body, like the NEB, to partially or completely fulfill its consultation obligations so long as the administrative body possesses the statutory powers to do what the duty to consult requires in the circumstances. The Crown, however, retains ultimate responsibility for ensuring consultation is adequate and must supplement the measures taken by the regulatory process being relied upon where it does not achieve adequate consultation or accommodation. ${ }^{17}$ In Clyde River, the Supreme Court quashed the NEB's authorization, concluding that the consultation and accommodation efforts undertaken by the NEB in that case were inadequate. By contrast, in Chippewas, the Supreme Court concluded that the NEB's process was sufficient to satisfy the Crown's constitutional obligation to consult. activities for 30 days so that consultation and accommodation could take place. 
Clyde River and Chippewas support the view that the question to be asked in cases where the duty to consult arises is always whether the consultation undertaken in the circumstances was adequate. Any decision affecting Aboriginal rights that is made on the basis of inadequate consultation will not be in compliance with the duty to consult and, where challenged on judicial review, should be quashed. ${ }^{18}$ In Clyde River, the Supreme Court elaborated as follows:

If the Crown's duty to consult has been triggered, a decision maker may only proceed to approve a project if Crown consultation is adequate. Although in many cases the Crown will be able to rely on the NEB's processes as meeting the duty to consult, because the NEB is the final decision maker, the key question is whether the duty is fulfilled prior to project approval.... Accordingly, where the Crown's duty to consult an affected Indigenous group with respect to a project ... remains unfulfilled, the NEB must withhold project approval. And, where the NEB fails to do so, its approval decision should ... be quashed on judicial review. ${ }^{19}$

The duty to consult is a constitutional obligation. It does not depend on whether the government participates in the consultation process, and it does not disappear when the Crown acts through a statutory body. Rather, "[i]t must be discharged before the government proceeds with approval of a project that could adversely affect Aboriginal or treaty rights." 20

The Chippewas and Clyde River decisions provide a clear way out of the legal vacuum created by Neskonlith, outlining roles for the entities seized with the issue, and a role for the Crown acting through its departmental representatives. In Part V of this comment, we provide suggestions on how municipalities and the provincial Crowns can coordinate their activities to take advantage of both the local knowledge of the municipality and the broader expertise of the province.

\section{WHY THE NESKONLITH DECISION IS UNWORKABLE ON THE GROUND}

In addition to creating a legal void in the application of the Crown's consultation obligations, the Court of Appeal's decision in Neskonlith poses implementation challenges. While the Crown retains the constitutional imperative to consult, the Crown's options for accommodating the Aboriginal rights at stake are severely limited where local decisionmakers are freed from any obligation to consult with affected Indigenous people. For instance, in situations where the consultation process between the Crown and the affected Indigenous group reveals significant potential adverse effects on existing or asserted Aboriginal rights arising in connection with a proposed project, the Crown would not be able to prevent the municipality from proceeding with the project. The Crown would also be limited in its ability to offer project alternatives to avoid or mitigate the infringement of the rights in question. Canadian courts have ruled that, as part of the consultation and accommodation process, the Crown must demonstrate a willingness to consider and address Indigenous interests. ${ }^{21}$ This may require the Crown to change its plans, proposed actions, and

Clyde River, ibid at para 24; Chippewas, ibid at para 32.

Clyde River, ibid at para 39 [citations omitted] [emphasis added].

Chippewas, supra note 3 at para 36 [footnotes omitted].

Haida, supra note 8 at para 27. 
policies. ${ }^{22}$ The Crown's inability to take these steps in the context of municipal decisions would effectively render the consultation process meaningless and fall short of the Crown's constitutional obligations.

As the Supreme Court of Canada has explained, "the duty to consult and accommodate is part of a process of fair dealing and reconciliation." "23 A situation where a municipality may freely infringe an Indigenous group's Aboriginal rights simply because it has no obligation to consult the Indigenous group is much more likely to increase the potential for conflict than encourage reconciliation. Allowing municipalities to proceed blindly while Indigenous groups have no effective remedy to address their concerns can also end in physical confrontations. This was the case in Oka, Quebec in 1990, where a proposal by the mayor to establish a golf course on land claimed by the Mohawks sparked a 78 day confrontation between the Canadian army and the Mohawks of Kahnawake. ${ }^{24}$ Similarly, in 2006, a decision by the municipality of Haldimand County, in Caledonia, Ontario, permitting a developer to acquire land claimed by the Six Nations Confederacy for housing development sparked the Six Nations' occupation of the site to prevent construction from proceeding. The occupation turned into a barricaded standoff, which lasted for three months, while the occupation continued until 2010. The occupation and blockade caused tensions within the local community, led to physical and verbal confrontations, and resulted in multiple lawsuits. The dispute was eventually settled when the provincial government purchased the land in issue from the developer. ${ }^{25}$

In the spirit of avoiding such conflicts with Indigenous groups, many municipalities are currently consulting with Indigenous peoples when undertaking activities that are likely to have an impact on their Aboriginal rights. ${ }^{26}$ In Neskonlith, for instance, the Court of Appeal noted that the City of Salmon Arm had taken good faith steps to engage the First Nation in the process of reviewing the proponent's development proposal. The Court concluded that, if the municipality had been required to consult, the steps it took would have fulfilled the duty:

The Neskonlith were treated respectfully by the City and its staff; they were given copies of all relevant materials; they were heard at various meetings; their expert reports were obviously reviewed with care by the owner's experts; and various modifications, including the reduction of the development to only 20 acres, were made by Shopping Centres to its plans in the process. $^{27}$ Haida, supra note 8 at para 32 .

Steve Bonspiel, "The Oka Crisis Was Supposed to Be a Wake-Up Call. Little Has Changed in 27 Years," CBC News (11 July 2017), online: < https://www.cbc.ca/news/opinion/oka-crisis-anniversary1.4197880>; Geoffery York \& Loreen Pindera, People of the Pines: The Warriors and the Legacy of Oka (Toronto: Little, Brown \& Company (Canada), 1991).

25 Indigenous and Northern Affairs Canada, "Chronology of Events at Caledonia" (February 2009), online: $<$ https://www.aadnc-aandc.gc.ca/eng/1100100016337/1100100016338>; "Buying Caledonia Land Will Cost Ontario Government \$12.3M," CBC News (23 June 2006), online: <https://www.cbc.ca/news/ canada/toronto/buying-caledonia-land-will-cost-ontario-government-12-3m-1.576496>. Colleen Sheppard, "Inclusion, Voice, and Process-Based Constitutionalism" (2013) 50:3 Osgoode Hall LJ 547.

Neskonlith, supra note 1 at para 89. 
There are other examples of municipal governments and Indigenous groups successfully engaging with one another. At the time the Court of Appeal issued its decision in Neskonlith in 2012, there were already hundreds of agreements in place between Indigenous communities and local governments. ${ }^{28}$ Academics Christopher Alcantara and Jen Nelles have gathered and analyzed agreements between Indigenous communities and local governments from across Canada. Their research shows a striking increase in the number of formal agreements entered into between Indigenous groups and municipal governments "beginning in the 1980s and accelerating through the 1990s and 2000s."29 The Court of Appeal's decision in Neskonlith does not appear to have done anything to stop these agreements from continuing to develop. Rather, the trend throughout the current decade shows such Indigenous-municipal agreements increasing in both frequency and complexity. While service type agreements, where municipalities provide services to Indigenous communities in exchange for payment, remain the most popular type of Indigenous-municipal agreement, Alcantara and Nelles note that agreements focused on building relationships and partnerships between local governments and Indigenous communities have become the second most commonly used agreement form. ${ }^{30}$ All of this suggests that, as a practical matter, agreements at the local intergovernmental level work and municipalities are not relying on Neskonlith to ignore their Indigenous neighbours.

Nor has the Neskonlith decision stopped provincial governments from requiring local governments to consult with Indigenous groups where Aboriginal rights may be affected by the exercise of their municipal powers. ${ }^{31}$ For example, Ontario's 2014 Provincial Policy Statement under the Planning $\mathrm{Act}^{32}$ requires that the Policy "be implemented in a manner that is consistent with the recognition and affirmation of existing Aboriginal and treaty rights in section 35 of the Constitution Act, 1982" 33 and "recognizes the importance of consulting with Aboriginal communities on planning matters that may affect their rights and interests." ${ }^{34} \mathrm{As}$ well, amendments to Alberta's Municipal Government Act, ${ }^{35}$ enacted in June 2017, now impose consultation requirements on municipalities located adjacent to existing Indian reserves or Métis settlements. ${ }^{36}$

See Christopher Alcantara \& Jen Nelles, A Quiet Evolution: The Emergence of Indigenous-Local Intergovernmental Partnerships in Canada (Toronto: University of Toronto Press, 2016) which provides an analysis and survey of Indigenous-municipal intergovernmental agreements gathered from across Canada and a more in-depth review of four particular agreements. See also Ontario, Ministry of Municipal Affairs and Housing, "Municipal-Aboriginal Relationships: Case Studies" (Toronto: Queen's Printer for Ontario, 2009), online: <www.mah.gov.on.ca/Page6054.aspx > which provides examples of intergovernmental agreements from across Ontario. For a case study, see Clara MacCallum Fraser \& Leela Viswanathan, "The Crown Duty to Consult and Ontario Municipal-First Nations Relations: Lessons Learned From the Red Hill Valley Parkway Project” (2013) 22:1 Can J Urban Research 1. Alcantara \& Nelles, ibid at 25.

Ibid at 26-28.

See Felix Hoehn \& Michael Stevens, "Local Governments and the Crown's Duty to Consult" (2018) 55:4 Alta L Rev 971.

RSO 1990, c P-13.

Ontario, Ministry of Municipal Affairs and Housing, Provincial Policy Statement: Under the Planning Act (Toronto: Queen's Printer for Ontario, 2014) at Policy 4.3, online: <www.mah.gov.on.ca/Asset Factory.aspx?did=10463> [Provincial Policy Statement].

Ibid at 4.

RSA 2000, c M-26.

Sections 636(1)(g) and (h) of the Municipal Government Act, ibid provide as follows:

(1)While preparing a statutory plan a municipality must

(g) in the case of a municipal development plan, notify (i)the Indian band of any adjacent Indian reserve, or (ii)any adjacent Metis settlement 
A review of court cases which have considered or applied Neskonlith is another indication of its negligible impact. Of the cases citing Neskonlith, four only cite the case for the standard of review, ${ }^{37}$ two focus on the decision in the context of the Court's review of provincial Crown conduct, ${ }^{38}$ another two cases arise from dissident groups challenging an existing agreement between a municipality and an Indigenous group, ${ }^{39}$ one cites the decision for the legal principle relating to potential grounds for appeals,${ }^{40}$ and one case deals with the Court's review of a decision by a school board to close schools. ${ }^{41}$ In other words, there is not a single case that turns on the fact situation envisioned by Neskonlith, where a municipality purported to change the use of land without consulting an Indigenous group. The limited application of this case suggests that municipalities have not been aggressively proceeding with projects in the face of Indigenous concerns, and may even be evidence of increasing cooperation between local governments and the Indigenous groups potentially impacted by their activities.

\section{The Role OF MUNiCIPALITIES IN DischaRgING THE Duty to Consult AND ACCOMmodate}

In deciding the appeals in Clyde River and Chippewas, the Supreme Court of Canada considered and clarified the nature of the Crown and its role in fulfilling the duty to consult in relation to the NEB. While the NEB could fulfill some of the duties to consult and accommodate, it was also limited by its statutory mandate. In this section we argue that the relationship between the Crown and municipalities is analogous to that between the Crown and the NEB.

\section{A. What is the Overall Role of the Crown in Consultation?}

The Crown is ultimately responsible for satisfying the duty to consult. However, as explained above, where the duty to consult is triggered, the Supreme Court of Canada confirmed that the Crown may rely on a regulatory agency's process to fulfill its duty to consult in whole or in part and, where appropriate, accommodate. Whether a regulatory agency's process is sufficient to meet the duty to consult will depend on whether the body has sufficient statutory duties and powers to provide an appropriate level of consultation and accommodation to the affected Indigenous peoples in the circumstances. As ultimate responsibility for ensuring the consultation is adequate remains with the Crown, if the

of the plan preparation and provide opportunities to that Indian band or Metis settlement to make suggestions and representations, and

(h) in the case of an area structure plan, where the land that is the subject of the plan is adjacent to an Indian reserve or Metis settlement, notify the Indian band or Metis settlement of the plan preparation and provide opportunities for that Indian band or Metis settlement to make suggestions and representations. Cold Lake First Nations v Alberta (Tourism, Parks and Recreation), 2013 ABCA 443 at para 38; Nunatsiavut Government v Canada (Department of Fisheries and Oceans), 2015 FC 492 at para 109; Prophet River First Nation v British Columbia (Environment), 2017 BCCA 58 at para 49; West Moberly First Nations $v$ British Columbia (Energy and Mines), 2014 BCSC 924 at para 8.

38 Halalt First Nation v British Columbia, 2012 BCCA 472; Squamish Nation v British Columbia (Community, Sport and Cultural Development), 2014 BCSC 991.

39 Smerek v Areva Resources Canada Inc, 2014 SKQB 282; McClung v Haudenosaunee, 2016 ONSC 1733 .

$40 \quad$ Wang $v$ Grace Canada Inc, 2018 BCCA 255 at para 29.

41 Snuneymuxw First Nation v Board of Education - School District \#68, 2014 BCSC 1173. 
regulatory process relied on does not achieve adequate consultation or accommodation, the Crown must take further measures to fulfill the duty. ${ }^{42}$

The Supreme Court further explained that the regulatory processes relied on to fulfill the Crown's consultation obligations need not be specifically tailored to consultation with Indigenous peoples. Rather, processes originally designed for a different purpose may still be relied on by the Crown to fulfill the duty to consult, "so long as [the process] affords an appropriate level of consultation to the affected Indigenous group." ${ }^{43}$ The regulatory body must have both the procedural powers necessary to implement consultation, and the remedial powers to accommodate affected Indigenous claims or Aboriginal rights. ${ }^{44}$

\section{B. What Entities Carry OUT THE Role OF THE CROWN?}

The Supreme Court also clarified how the NEB's decision qualified as Crown conduct triggering the Crown's duty to consult. In Clyde River, the Supreme Court explained the role of the NEB vis-à-vis the Crown as follows:

[T] he NEB is not, strictly speaking, "the Crown". Nor is it, strictly speaking, an agent of the Crown, since - as the NEB operates independently of the Crown's ministers - no relationship of control exists between them.... As a statutory body holding responsibility under s. 5(1)(b) of [the Canada Oil and Gas Operations $A c t^{45}$ ], however, the NEB acts on behalf of the Crown when making a final decision on a project application. Put plainly, once it is accepted that a regulatory agency exists to exercise executive power as authorized by legislatures, any distinction between its actions and Crown action quickly falls away. In this context, the NEB is the vehicle through which the Crown acts.... It therefore does not matter whether the final decision maker on a resource project is Cabinet or the NEB. In either case, the decision constitutes Crown action that may trigger the duty to consult. ${ }^{46}$

The NEB is a statutory body with delegated executive responsibility to make decisions that could adversely affect Aboriginal rights. In both Clyde River and Chippewas, the NEB acted on the Crown's behalf in approving each proponent's application. Because the projects in issue in each case had the potential to adversely affect the Aboriginal rights of the appellant Indigenous groups, the Crown had an obligation to consult with respect to the proponents' applications. ${ }^{47}$ Therefore, in each case, the NEB's approval process itself was the Crown action that triggered the Crown's duty to consult. This was the case notwithstanding the fact that the Crown was not a party to the regulatory process. ${ }^{48}$

Clyde River, supra note 3 at para 22.

Ibid at para 31 [citations omitted].

Ibid at paras $31-32,34$.

RSC 1985, c O-7.

Clyde River, supra note 3 at para 29 [citations omitted].

Chippewas, supra note 3 at para 31.

Clyde River, supra note 3 at para 29. 


\section{Application in the ConteXt OF Municipalities}

The reasoning of the Supreme Court of Canada in Clyde River and Chippewas helps address the concerns raised by the Court of Appeal in Neskonlith regarding the role of municipalities in discharging the duty to consult. In Clyde River, the Supreme Court noted that statutory bodies, like the NEB, were neither the Crown nor agents of the Crown. However, such statutory bodies, with delegated executive responsibility to make final decisions on project applications, acted on behalf of the Crown when exercising this responsibility. In the cases of Clyde River and Chippewas, the NEB became "the vehicle through which the Crown acts" and its decision, undertaken in accordance with its delegated authority, constituted "Crown action that may trigger the duty to consult."49

Similarly, municipalities are creatures of statute with the legislated authority and responsibility to make certain final decisions. In making these decisions, municipalities act on behalf of the Crown, and such decisions become Crown action subject to the Crown's consultation obligations. Where such decisions have the potential to affect Aboriginal title and rights, the Crown's duty to consult is triggered. In these circumstances, the municipalities should be required to ensure the duty to consult and accommodate Indigenous people respecting their concerns has been sufficiently discharged before proceeding with a decision or activity.

Municipalities should engage in consultation with affected Indigenous groups regardless of whether it is a legislative requirement of the governing statute. Where the consultation efforts undertaken by the municipalities are insufficient, or where municipalities lack the remedial powers to adequately accommodate Indigenous concerns, then the provincial Crown must take further steps to ensure the duty to consult is properly discharged.

Felix Hoen and Michael Stevens suggest that the powers delegated to local governments in modern day life are the same as those assumed by the Crown over lands formerly controlled by Indigenous peoples ${ }^{50}$ For this reason, local governments should exercise their powers in a manner consistent with the honour of the Crown and comply with the Crown's duty to consult.

In coming to this conclusion, Hoehn and Stevens draw comparisons between the application of section 35 of the Constitution Act, 1982 and the application of the Canadian Charter of Rights and Freedoms ${ }^{51}$ to municipalities. Courts have consistently found municipalities to be bound by the Charter, despite the fact that they are not identified in

Hoehn \& Stevens, supra note 31 at 977.

Part I of the Constitution Act, 1982, being Schedule B to the Canada Act 1982 (UK), 1982, c 11 [Charter]. 
section 32(1) of the Charter. ${ }^{52}$ As the Supreme Court of Canada noted in Godbout v. Longueuil (City), ${ }^{53}$

\begin{abstract}
interpreting s. 32 as including governmental entities other than those explicitly listed therein is entirely sensible from a practical perspective. Were the Charter to apply only to those bodies that are institutionally part of government but not to those that are - as a simple matter of fact - governmental in nature (or performing a governmental act), the federal government and the provinces could easily shirk their Charter obligations by conferring certain of their powers on other entities and having those entities carry out what are, in reality, governmental activities or policies.... Clearly, this course of action would indirectly narrow the ambit of protection afforded by the Charter in a manner that could hardly have been intended and with consequences that are, to say the least, undesirable. ${ }^{54}$
\end{abstract}

The Supreme Court in Godbout concluded that Charter rights were so fundamentally important that they required safeguard from possible attempts to unduly narrow their scope or circumvent their obligations. ${ }^{55}$ According to Hoehn and Stevens, this same logic should require municipalities to act in a manner consistent with section 35 of the Constitution Act, $1982^{56}$ and the constitutional duty to consult.

Both the reasoning of the Supreme Court of Canada in Clyde River and Chippewas and the rationale provided by Hoehn and Stevens point to municipalities being some sort of emanation of the Crown and therefore bound by the Crown's duty to consult to the extent that municipal legislation permits.

However, even if we assume, for the sake of argument, that municipalities are not emanations of the Crown, but rather corporate "creatures of statute" unrelated to the Crown, we would still conclude that municipal projects could not proceed until consultation and accommodation had first taken place. If municipal corporations, like business corporations, are "creatures of statute" independent of the Crown, they arguably have no duty to consult. However, as confirmed in Ross River Dena, and hundreds of other duty to consult cases, business corporations are not permitted to proceed with their proposed activity until the Crown has fulfilled its obligations to consult and accommodate. It would be very odd to allow municipal corporations, in their capacity as corporations, to proceed with a project without any consultation, while prohibiting business corporations from doing so.

In conclusion, it seems clear to us that municipalities must take on the responsibility of consulting Indigenous people impacted by their development activities. If they are unable to fulfill this responsibility adequately, the Crown must step in. In either case, the municipality cannot proceed with a project until the duty to consult has been fulfilled.

Ibid, $\mathrm{s} 32(1)$.

[1997] 3 SCR 844 [Godbout].

Ibid at para 48 .

Ibid.

Being Schedule B to the Canada Act 1982 (UK), 1982, c 11. 


\section{How Can We Coordinate Municipal Consultation With Provincial Crown Responsibility?}

While the Court of Appeal in Neskonlith emphasized the "mundane" administrative nature of decisions made by municipal governments, the reality is that these decisions often have very real, and usually immediate, consequences for the people affected by them, including Indigenous people. Given the legal and practical implications of municipalities not consulting with potentially impacted Indigenous groups, we propose that it is in the best interest of all parties involved for a space to be carved out for municipal participation in the consultation process.

\section{A. Municipalities Should Lead Consultation and Accommodation, But the Provincial Crown SHOULD SUPPLEMENT AS NECESSARY}

In justifying the ability of regulatory bodies to fulfill the Crown's duty to consult, the Supreme Court in Clyde River took special note of the NEB's institutional expertise in undertaking consultation and in assessing the environmental impacts of proposed projects, concluding as follows:

Where the effects of a proposed project on Aboriginal or treaty rights substantially overlap with the project's potential environmental impact, the NEB is well situated to oversee consultations which seek to address these effects, and to use its technical expertise to assess what forms of accommodation might be available. ${ }^{57}$

Municipalities likewise have specific expertise that may make them better suited to fulfill certain aspects of the duty to consult and accommodate in respect of local matters. As the Neskonlith First Nation argued before the Court of Appeal:

Local governments, as the decision-makers regarding land use decisions that could affect the exercise of Aboriginal Title and Rights, are in the best position to engage in the consultation process. They are located in the area where the proposed development is proposed to take place and have a better understanding of the local circumstances than centralized governments. ${ }^{58}$

The Court of Appeal in Neskonlith ultimately dismissed the Neskonlith First Nation's argument in this regard, concluding that the limitations of municipalities in fulfilling the requirements of consultation outweighed the benefits of extending some aspect of the obligation to them. However, the fact remains that, notwithstanding the Crown's ability to rely on regulatory, or, as we argue in this comment, municipal, processes to fulfill its consultation obligations, the Crown retains ultimate responsibility for ensuring the adequacy of consultation. Therefore, the question of whether a municipal process is sufficient to discharge the Crown's duty to consult and accommodate is one to be determined by the Crown on a case-by-case basis. As with regulatory processes, where consultation processes undertaken by a municipality do not achieve adequate consultation or accommodation, the Crown will be expected to take further measures to meet the duty. As noted in Clyde River, 
this may require the Crown to make submissions to the statutory body, request reconsideration of a decision, or seek a postponement to allow further consultation in a separate process, or it may require the Crown to pursue legislative or regulatory amendments. ${ }^{59}$

It would likely not be efficient for every proposal by every municipality to be approved or reviewed by a central agency in the provincial government. We therefore suggest that municipalities work with affected Indigenous groups to conduct an initial assessment of the municipality's capabilities to undertake consultation with the affected Indigenous groups, and that they contact the provincial government for assistance or support as required. In this way, project proposals that are at the lower end of the consultation spectrum could be undertaken between municipalities and impacted Indigenous communities without provincial involvement. Such a formalized process between local and provincial governments would not prejudice Indigenous groups because the overall responsibility of the provincial Crown would not change. All that would happen is that there would be a more efficient and transparent sharing of the consultation activities between the province and the municipality.

We can see how these consultation issues played out in a case decided by the Ontario Municipal Board (OMB) shortly after Clyde River and Chippewas were decided. In Burleigh Bay Corporation v. North Kawartha (Township), ${ }^{60}$ the defendant township turned down an application for the development of a condominium complex in Ontario. The developer appealed the rejection to the OMB. The OMB was required to determine whether the proposed development was consistent with Ontario's Provincial Policy Statement, which includes requirements to consider the cultural and heritage interests of local Aboriginal people. ${ }^{61}$ A local First Nation participated in the hearing, raising concerns about the potential impacts of the development on its archaeological sites and artifacts and the lack of consultation respecting the development.

The OMB dismissed the application on other grounds, but found that consultation was adequate in this case. In considering the duty to consult issue, the OMB attempted to follow the analysis set out in the Chippewas case. The Board reviewed the consultation undertaken by the developer itself, and also the fact that the local First Nation was given participant status in the hearings before the OMB. Taking into account the degree of impact on the interests of the First Nation, the OMB found that deep consultation was not necessary, and that the requirement for consultation had been fulfilled. ${ }^{62}$ The adequacy of the consultation and accommodation by the township was not in issue in this case because the township opposed the development as well. However, had the township favoured the development, the OMB would have had a framework to evaluate the adequacy of the consultation and accommodation undertaken by the township in deciding whether the duty to the First Nation had been fulfilled. If the OMB had found that the consultation and accommodation process was inadequate because the participation of the provincial Crown was required, the Board could have refused to allow the project to proceed until the Crown had stepped in to supplement the steps already taken. 


\section{B. Municipalities Can Be Directed to Discharge THE DUTY TO CONSUlt THROUGH LEgISLATION, Policy, OR in Practice}

In Part III of this article, we outlined a number of ways that consultation by municipalities can be addressed. In Alberta, the Municipal Government Act specifically requires municipalities to allow Indian bands and Métis communities the opportunity to make suggestions and representations in the planning context. ${ }^{63}$ In Ontario, the Provincial Policy Statement recognizes the importance of consultations by municipalities on planning matters. ${ }^{64}$ Finally, the work of Alcantara and Nelles documents hundreds of agreements entered into between municipalities and Indigenous peoples. ${ }^{65}$ In our view, all of these methods are legitimate bases for consultation by municipalities, and all are currently being utilized.

Collaboration between provinces, municipalities, and Indigenous peoples can be facilitated by having provinces and Indigenous communities provide education and training to municipalities on ways to recognize potential issues and interact with their Indigenous neighbours. For instance, Indigenous governments may have their own consultation and engagement protocols in place, which they can share with municipalities to help guide these interactions and facilitate discussions. In other circumstances, Indigenous communities and municipalities could work together to develop their own engagement framework based on their specific priorities. Other initiatives could also support municipal-Indigenous consultation processes. In Ontario, for example, the Shared Path Consultation Initiative, a grassroots organization training First Nations and municipal staff on how to conduct meaningful and respectful consultation, serves as an example of the potential for multigovernment collaboration. ${ }^{66}$ Whatever model is developed, provinces should make clear what services they will provide to municipalities, taking into account the size and capacity of the municipality involved. For instance, larger municipalities may be expected to maintain a greater degree of responsibility for the consultation and accommodation process than smaller municipalities.

\section{Conclusion}

We have argued that Neskonlith was wrong in law in that it focused on whether the municipality had a duty to consult, and not on whether appropriate consultation and accommodation had taken place. Like private corporations, municipalities should not be permitted to proceed with activities that have the potential to affect the rights of Indigenous people unless the Crown has first fulfilled its duty to consult. In our opinion, the Supreme Court of Canada's reasoning in Clyde River and Chippewas rejects the suggestion by the Court of Appeal in Neskonlith that Indigenous peoples potentially impacted by decisions of local government should seek recourse for the Crown's failure to consult in some other forum. In Clyde River, the Supreme Court of Canada made clear that "judicial review is no

Supra note 35 , ss $636(1)(\mathrm{g})-(\mathrm{h})$.

Supra note 33.

Supra note 28.

Shared Path Consultation Initiative, online: $<$ sharedpath.ca/>. 
substitute for adequate consultation." ${ }^{97}$ Consultation is meant to achieve reconciliation between the Crown and Indigenous peoples, and "[t]rue reconciliation is rarely, if ever, achieved in courtrooms."

We have also shown that Neskonlith could not be implemented on the ground, and that in practice, it has had only a tangential impact on what municipalities actually do. It simply is not practical for local governments to ignore the interests of their Indigenous neighbours. Municipalities should facilitate consultation and accommodation within their jurisdictions. However, the provincial Crown may be required to supplement these activities where a municipality's resources are limited and the matter calls for additional expertise. Ultimately, a coordinated municipal-provincial approach to consulting Indigenous groups on local matters that have the potential to affect their rights is the most efficient way to proceed. 
[this page is intentionally blank] 